\title{
TV/Series
}

15 | 2019

La Sérialité en question(s)

\section{Becoming Morse in Endeavour: the prequel as locus of reconstruction of the past?}

\section{Armelle Parey}

\section{(C) OpenEdition}

1 Journals

\section{Electronic version}

URL: http://journals.openedition.org/tvseries/3751

DOI: 10.4000/tvseries.3751

ISSN: 2266-0909

\section{Publisher}

GRIC - Groupe de recherche Identités et Cultures

\section{Electronic reference}

Armelle Parey, «Becoming Morse in Endeavour: the prequel as locus of reconstruction of the past? », TV/Series [Online], 15 | 2019, Online since 16 July 2019, connection on 20 July 2019. URL : http:// journals.openedition.org/tvseries/3751 ; DOI : 10.4000/tvseries.3751

This text was automatically generated on 20 July 2019

\section{(c) (i) (2)}

TV/Series est mis à disposition selon les termes de la licence Creative Commons Attribution - Pas d'Utilisation Commerciale - Pas de Modification 4.0 International. 


\title{
Becoming Morse in Endeavour: the prequel as locus of reconstruction of the past?
}

\author{
Armelle Parey
}

\section{Introduction}

1 The figure of Inspector Morse first appeared in a novel by Colin Dexter, Last Bus to Woodstock, in 1975. By the time the character reached the TV screen in 1987, impersonated by John Thaw (in The Dead of Jericho), Colin Dexter (1930-2017) had already published 7 of the 12 novels he wrote in total around the figure of the grumpy operaloving inspector. The TV adaptation, Inspector Morse, consisted in 33 films, broadcast in series or as "specials", aired on ITV between 1987 and 2000, finishing with the adaptation of The Last Remorseful Day (1999) in which the character dies ${ }^{1}$. Following the death of John Thaw in 2002, Dexter stipulated in a clause in his will that no other actor should reprise the role ${ }^{2}$.

2 This limitation was no obstacle to the making of Inspector Lewis (ITV, 2006-2015), which was approved by Dexter ${ }^{3}$, and whose pilot, according to David Bishop, "became the highest rating drama of the year". This series is often referred to as a spin-off since it is built around Morse's sidekick played by Kevin Whately, a secondary character now turned central ${ }^{5}$. If no one could reprise the role of Morse impersonated by John Thaw nor could a sequel be considered, it was however possible to imagine a prequel with a younger version of Morse, which is both the same and different from the Dexter/Thaw creation. Endeavour, a Mammoth Screen production for ITV, was first aired in 2012 for the $25^{\text {th }}$ anniversary of Morse's first TV appearance. With 6 seasons and a total of 27 films aired so far, this new series with Russell Lewis (who also devised the story of the pilot for Lewis) as unique writer 6 , has introduced the audience to young Morse, played by Shaun Evans, at the time of his first years as police in Oxford. This series thus qualifies as a prequel since it is set earlier in time than its source narrative. Before going any further, it 
is worth pointing out that the question of the source narrative seems particularly interesting in the case of Endeavour: this TV series is derived not directly from a source text but from a TV series adaptation of a source text; in other words, this prequel is derived from two sources: the TV adaptation and the source text to that first TV series, potentially an example of what Linda Hutcheon calls "multilaminated" adaptations or "the audience's "palimpsestuous" intertextuality". To some extent, it illustrates Jason Mittell's idea that a contemporary serial text is "a sprawling library of narrative contents ${ }^{8}$ " or, as Yvonne Griggs puts it, "a product that has its genesis in an array of textual sites".

Famous prequels on the screen include the Star Wars trilogy released after the first one but that goes back in time. More recently and similarly to our corpus, Han Solo's youth was narrated in Solo (dir. Ron Howard, 2018). Like these, Endeavour corresponds to what Gérard Genette calls an "analeptic" continuation that works its way upstream ${ }^{10}$. In fact, the prequel constructs "a prehistory ${ }^{11}$ ", literally the period before written records, before the storyworld penned down by Colin Dexter in the Morse series ${ }^{12}$. In so doing, the prequel reconstructs the past on the basis of threads in the source narrative: after discussing the specificities of the prequel genre in relation to Endeavour ${ }^{13}$, this paper purports to examine the transformative effects of this reconstruction: how the prequel may or may not reconstruct the past of the hero, and how in so doing it may also reconstruct the memory of the viewer, his or her perception of the past, in terms of the source narrative but also of its setting.

\section{A prequel and a TV series}

4 Endeavour is a prequel because it goes back to the character's past and purports to give the beginnings of Morse's career in the mid-1960s, how he came to join Oxford police, etc 14. Endeavour is also a TV series and it will be worth considering how the principle of the prequel combines here with the genre of the TV series and its specific codes and dynamics.

Because the reader already knows what happens next, prequels might seem to go against the usual run of narrative desire which is commonly considered to be future-orientated ${ }^{15}$. But, as Ben Davies observes,

The temporal excitement and tension derive from a known narrative trajectory and teleology, and the spatiotemporal flirtation, pause and delay of the prequel. Prequels project a narrative movement towards their related narratives ${ }^{16}$.

6 The narrative progression and drive of the prequel is indeed the usual one, from beginning to end.

7 It can also be argued, as $\mathrm{H}$. Porter Abbott does, that the narrative drive actually works both ways. For him, suspense, "the engine of narrative", is "the pleasing ache of wanting to know what has happened or what will happen next, and has the audience straining to look back or ahead ${ }^{17}$." Moreover, as pointed out by Raphaël Baroni amongst others, suspense can be effective even if one knows the end of the story because of the reader's emotional involvement and identification ${ }^{18}$. Finally, there is obviously pleasure to be derived from a form of retrospection: understanding how things came to be the way they are ${ }^{19}$.

If the end is already defined - Endeavour will become the Morse viewers know - what happens in between offers a wealth of possible events and stories and TV episodes. Moreover the temporal distance between source text and prequel may vary greatly. In 
the particular case of Endeavour, over twenty years separate the narratives. It can also be noted the prequel does not join up with Morse (as Jean Rhys's Wide Sargasso Sea joins Charlotte Brontë's Jane Eyre): there is therefore no challenge in knowing how the prequel will link up to its source text.

9 Looking at TV series, Stéphane Benassi explains that they follow a matrix or formula which encompasses a set of "invariable elements ${ }^{20 "}$ " from which variable ones can then be derived. The five fields covered by this dialectical notion of variable/invariable are "semantic, spatial, temporal, narrative and discursive ${ }^{21}$ ". A TV series prequel will then reprise the matrix of its source narrative but transpose it to an earlier period, with its set of invariables. Prequels and sequels indeed tend to remain in the same genre as their source narrative ${ }^{22}$. ITV's Endeavour is indeed a detective series, in the same two-hour format including commercial time, which gives time to develop the characters.

However, significant changes have occurred in the making of TV series since the 1990s of Inspector Morse. According to Tzvetan Todorov, what matters in classical detective fiction is the story of the crime ${ }^{23}$. The rest, Todorov's "story of the investigation", is relatively secondary ${ }^{24}$ with little fleshing out of the characters. Jean-Pierre Esquenazi has argued that the unusually slow pace of the Morse films at the time is there to allow "the fleshing out of the narrative universe ${ }^{25}$ ". This "fleshing out" has largely been developed in Endeavour, an instance of the development of more complex formats for TV series ${ }^{26}$. Morse films are classically conceived as individual films in a series, and sometimes were just released on their own ${ }^{27}$. Endeavour follows a contemporary format, according to which "[s]eries embrace a balance between episodic and serial form, allowing for partial closure within episodes while maintaining broad narrative arcs across episodes and even seasons ${ }^{28}$. Endeavour films thus display the closed unity of the source series as every episode solves the mystery presented at its beginning. But, significantly, the relationships between the characters evolve as we learn more and more about the protagonists' private lives $^{29}$. Endeavour's first season thus develops the relationship between young Morse and his superior Fred Thursday but also with his family ${ }^{30}$. Each season has its own dynamic but there is also an added overall temporal movement that allows for character development: the series begins in 1965 and the last one released to date was set in 1968 . In the course of the seasons, we thus see for instance, the future Superintendant Strange rise in the hierarchy as Morse first fails to become sergeant because his exam paper has gone missing $(\mathrm{S} 03-04)^{31}$.

\section{Reconstructing Morse?}

11 Endeavour picks up a famous character, well-known both on the page and on the TV screen, with a fixed set of characteristics. As Carolyn Jess-Cooke observed about film, "the prequel is concerned with the origins of a narrative or character ${ }^{32}$ ", which is a constraint: in Aristotle's words: “A beginning is that which is not a necessary consequent of anything else but after which something else exists or happens as a natural result ${ }^{33}$ ". The origins or beginnings of Endeavour Morse devised by Russell Lewis, so far the only scriptwriter for Endeavour, have to fit in with what is known to come next. Endeavour, as a prequel, is bound by the Morse novels and films: it can contradict the existing Morse neither physically, psychologically nor narratively. We know what the character becomes: a solitary, grumpy, whisky and beer-loving detective with a marked taste for crosswords and for classical music; we know that any romantic involvement developed in Endeavour, 
whether over a single episode (for instance in "Rocket" S01E03) or over a season or more (such as his relationship with his neighbour), is doomed as Morse must remain single and solitary. In Colin Dexter's words, "But now the leaves were falling around him: midforties; unmarried; alone ${ }^{34 "}$. However, these aborted love stories in Endeavour contribute to the notion of the lonely, melancholic character, ever disappointed in matters of love, created by Colin Dexter and adapted to the screen. Indeed, in Dexter's first novel, Last Bus to Woodstock (1975), the detective becomes romantically involved with the character who turns out to be the murderer and in the first TV adaptation, The Dead of Jericho (ITV, 1987) the woman the inspector is interested in is the victim.

The first Endeavour film strongly establishes the link with Inspector Morse. Extradiegetically, the same theme music created by Barrington Pheloung is used again for opening and closing credits. Towards the end of the pilot film, Inspector Fred Thursday asks Morse how he sees himself in twenty years' time. Shaun Evans as young Morse looks into the car rear view mirror and the next shot of the rear view mirror reflects actor John Thaw's eyes. A prequel is generally closely related to a source narrative which it opens up: it furthers some element that has been left undeveloped in the source text or "antetext ${ }^{35}$ ". A narrative is always full of gaps waiting to be filled but this is particularly obvious in Dexter's series because, firstly, Morse is middle-aged, which leaves his youth to be imagined. According to David Bishop, "Dexter has [had] written very little about Morse's background - and what he has written frequently contradicts itself - so the project [of a prequel] would have a fairly free hand to craft new stories for the character ${ }^{36}$ ". Secondly, Morse is a fairly opaque character or part of a fairly elliptical narrative. Indeed, Colin Dexter's series is built around the figure of a detective whose thoughts we follow but about whom we know fairly little. In the very first novel in which he appears, Morse is described as "the enigmatic Chief Inspector 37 " who is characterized by his marked taste for whisky and ale ${ }^{38}$, crosswords ${ }^{39}$ - "crosswords were a passion with Morse $\mathrm{e}^{40}$ " opera - "he delighted in Wagnerian opera and had the complete cycle of The Ring ${ }^{41}$ ", his fussiness regarding spelling ${ }^{42}$. He went to Oxford university himself. He drives an old Jaguar $^{43}$ and despite his attraction for women and the fact they find him attractive, he remains single.

The most titillating mystery about Morse in Dexter's novels and in the TV adaptation was the inspector's first name $e^{44}$, a mystery that was re-enacted in almost every novel, until it was revealed in Death is Now My Neighbour (last but one novel and last but one film), a first name that now gives the prequel its title, suggesting closer intimacy or insight into the famous character's past.

14 Most of the characteristics that define Morse are set up in the first Morse film (that is not however the adaptation of the first novel by Colin Dexter) and most of them reappear in the first Endeavour film too. The main change to the character imagined by Dexter is that he lost his taste for pornography and became a more romantic character, which is the line followed by Endeavour too.

As a prequel, Endeavour deliberately plays on the well-known characteristics, as indicated on the website of Mammoth Screen Productions:

Shaun Evans (The Take, Come Rain Come Shine) will step in to John Thaw's shoes to play the younger version of Colin Dexter's iconic character, giving the audience the chance to discover the origins of the detective famed for his love of crosswords, classical music, real ale and classic cars ${ }^{45}$. 
It openly purports to imagine how Endeavour became Morse, to provide the "back story" or "origin story". To a certain extent, the pilot does just this and only this, focusing on the well-known characteristics: we see him starting to drink with Inspector Thursday, be sensitive to Thursday's car, and we learn how opera music was important to him in difficult times. As has been observed of other narrative expansions, "the hypotext is always kept at some spectral level, as more or less persistent literary memory "4". Only a few salient points are remembered and expanded upon: it is the idea of Morse that pervades Endeavour with the same few key traits resurfacing.

The link between prequel and source narrative having been established, Endeavour may

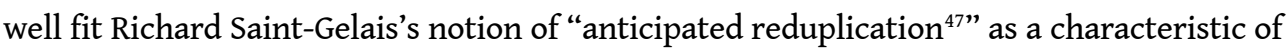
prequels. Saint-Gelais gives the example of Barry Levinson's film, Young Sherlock Holmes (1985), where we merely encounter the same character but younger, with the underlying idea that the prequel may present no originality. Originality may however not be at stake for the producers of Endeavour. The marketing team rather seems to be at pains to reinforce the link between the prequel and its source text. For instance, after the success of the 2012 pilot, episodes of Inspector Morse were shown each night on ITV3 (with a catch up service available on itvplayer) in the run up to the new 2013 Endeavour series, which suggests the need to accentuate the link or reactivate interest in the former series (Dexter's books were re-released again by Pan Macmillan in 2016). Even when the Endeavour series is obviously well established, the ITV website announcing the $6^{\text {th }}$ season reads: "Set in the 1960s, against a backdrop of revolutionary social change, Endeavour chronicles the early criminal casebook of a young detective who will grow to be Colin Dexter's immortal Inspector Morse ${ }^{48}$ ". Endeavour is indeed a "pre-loved story", part of this " upsurge in the number of serial narratives that have their origins in prior texts: whether transitioning from stage, film, novel, comic book, biography or memoir, [...] preloved stories are finding increased traction within a TV medium that is acutely aware of the financial advantages of harnessing an existing fan-base $e^{49}$. In fact, rather than pleasure in filling in the gaps, Endeavour, as a prequel TV series, might well offer pleasure in repetition or in the prequel's "anticipated reduplication". Prequels often entertain a marked strong intertextual relationship with their sources even if the audience will allow and expect relative (moderate) change due to the different period in time: these narrative expansions must thus compose with an existing character and the audience's expectations coupled with the fact that the end has already been reached and cannot be changed. Prequels build on a source narrative and deliberately reactivate key-elements that are significant for the reader/viewer. The same characteristics and mode of detecting are to be found in Endeavour as in Morse like the Sherlock Holmes-like attention to detail, intuition and deduction. Little allusions to the source narratives placed here and there remind the audience of the latter: Morse's necrophobia; Morse's unhappy love life (just as in the first novel where the detective becomes romantically involved with the character who turns out to be the murderer, the woman whom he admires and feels attracted to in the pilot for Endeavour turns out to the murderer). Yet, the transposition of the character to different times, with different actors, undeniably constitutes a departure from its sources. 


\section{Impact on memory}

18 The very production of Endeavour for the anniversary of Morse's first appearance on screen can be read as an instance of "this increased memorialisation of past television within the British context", namely "the reinvention and resurrection of cult or canonical texts $^{50 "}$. In fact, not only does Endeavour reactivate the memory of a popular hero for those who knew him, but it also creates the status of the Morse series as popular icon amongst the new viewers. Indeed, Endeavour tries to catch both "knowing and unknowing audiences ${ }^{51 "}$.

When exploiting the blank of Morse's young years in the police, the prequel actually engages the "knowing" viewers through the reinforcement of memory with the recurrence of characteristics but adaptation implies a modification of memory in the process: in John Ellis's words,

The adaptation trades upon the memory of the novel, a memory that can derive from actual reading, or [...] a generally circulated cultural memory. The adaptation consumes this memory, aiming to efface it with the presence of its own images ${ }^{52}$.

Rather than the erasure of memory mentioned by Ellis that is debatable ${ }^{53}$, the modification of memory is indeed a feature of narrative expansions. Michael Zeitlin acknowledges the impact of a subsequent text on the originally published one: "a text conventionally defined as a 'sequel' can work a transformative effect upon its precursor $[. . .]^{54}$ ". This is all the more true of the prequel because of its "peculiar dual temporality" underlined by Paul Sutton which "enables it [the prequel] to both precede and follow the film or films to which it is a prequel. The prequel, then, despite its precedence, is able to effectively remake the film or films to which it is in fact structurally and narratively anterior $^{55 "}$. A famous case in point in literature is offered by Jean Rhys's prequel (and coquel) to Charlotte Brontë's Jane Eyre in Wide Sargasso Sea. As Kathy Mezei puts it, having read Wide Sargasso Sea, "We can never encounter Bertha in Jane Eyre without thinking that we now know her true history ${ }^{56 "}$. Yet, as said above, Endeavour is not meant to challenge the original character but to celebrate and reactivate its memory since it was first produced for the anniversary of Morse's first appearance on screen. The aim is rather to provide pleasure through the reprisal of a well-known character.

21 Another noteworthy element when considering the issue of memory in this series is the fact that Endeavour goes back in time to the mid-1960s. Contrary to Morse and Inspector Lewis that are contemporary in the sense that the time of the narrative is the same as the time of broadcasting, the dichotomy between broadcasting time and narrative time in Endeavour makes the series a period piece, both building on and developing a sense of nostalgia in the viewer. One may notice the use of slightly sepia colour and lighting for drab indoor scenes where attention is paid to period details, from the women's hairstyles to props like telephones and Mrs Thursday's mechanical brush, etc.

Even though the Morse films were set in contemporary Britain, they are (repeatedly) said to offer a "nostalgic, sumptuous reconstruction of Oxford/England in all its architectural and cultural splendour ${ }^{57 "}$ and to offer, through a fictionalised present, a past in disguise ${ }^{58}$ and one might wonder if Endeavour, set in the past, also offers a nostalgic past or a present in disguise with current issues being introduced, as is often the case in historical fiction. McCaw (among others) has shown how the social or disturbing dimension of the Dexter novels was turned into individual stories, smoothed or erased on the TV screen ${ }^{59}$. 
The pilot for Endeavour seems slightly different from its source series: the film, built around a Pygmalion-type bet that leads to sexual abuse, denounces corruption in society at every level (a lord is made to resign), including within the ranks of the police, showing how the lower classes are instrumentalised and despised by the upper ones. It also shows the limitations of the police in the sense that Morse's direct superior beats up a suspect to get information.

Endeavour takes on board a few contemporary issues ${ }^{60}$ but overall remains quite moderate, if we compare the first seasons to the Inspector George Gently series (BBC, 2007-2017), also set in the 1960s, that deals more frontally with problems like prejudice against women and homosexuals or racism. On the whole, the first Endeavour series remains true to TV Morse in its unrelatedness to the social contemporary world: see for instance "Fugue" (S01E02), when the murderer kills and organises clues based on operas which only the detective can understand... "Rocket" (S01E03) represents and questions class distinctions but these are not related to the solution to the murders' investigation. This unrelatedness of the plots and murders to a social context is supported by similar shots of Oxford (its spires, its colleges, the Sheldonian theatre, etc.) in both Endeavour and Morse, displaying the atemporality of the city and suggesting the same of its fictional inhabitants.

\section{Conclusion}

As the prequel to a famous TV adaptation of a series of popular detective novels by Colin Dexter, ITV's Endeavour is intertextually and intermedially tied to Inspector Morse ${ }^{61}$. It is part of the continuing trend already observed in 2011 by Amy Holdsworth: "Recent years have seen the return of a variety of earlier television drama and comedy successes as remakes, re-imaginings, prequels, sequels and spin-offs populate the schedules ${ }^{62}$. This prequel however navigates both the issue of narrative curiosity and changes in the format of TV series since the 1990s. In this portrait of Morse as a young man in the mid-1960s, the character is reconstructed along its best-known and well-loved traits so as to reactivate the memory of the original series or to posit it as a popular icon to younger viewers. Contrary to Morse on the page or on the screen, Endeavour is conceived as a period work and the first season tends to offer a rather nostalgic view of the past, quite unrelated to its social issues. When interviewed Russell Lewis often mentions the importance of Colin Dexter who not only wrote the books but also contributed some scripts. Endeavour seems indeed designed primarily to appeal to the viewers who are knowing about Morse in books or on TV and who will enjoy the references to the source narrative. Picking up many of the characteristics of the series, the novelty in this prequel to Inspector Morse may reside in a large part from its updated TV series format that enables more insight in Morse's relationships. Yet, with a younger actor who belongs to a new generation and never watched the original series, Endeavour has certainly captured a new but similar audience not necessarily familiar with Morse nor with the 1960 s.

Because they are analeptical expansions, prequels somewhat place the source narrative in the position of the derived narrative $e^{63}$. In other words, and extrapolating a little, the derived series takes precedence: this may be visually true of Endeavour whose vintage aesthetic suits current taste and interpretation of the 1960s. Considering this series that began as commemoration has kept so many of the characteristics of the Morse series, it 
might be more accurate to suggest that it has adapted rather than supplanted it source narratives.

\section{NOTES}

1. Apart from the 12 novels that were adapted over the years, Dexter provided storylines for series 2. Accordin to Barry Forshaw, Dexter adapted his novels to the TV series. See Barry Forshaw, British Crime Film: Subverting the Social Order, Basingstoke, Palgrave Macmillan, 2012, p. 210.

2. Dennis Barker, "Colin Dexter obituary", The Guardian, 21 March 2017, https:// www.theguardian.com/books/2017/mar/21/colin-dexter-obituary, consulted 14 July 2019; Nick Clark, "The Morse Code: No other actors will be allowed to play Colin Dexter's detective after the late John Thaw", The Independent, 25 March 2014, https://www.independent.co.uk/artsentertainment/tv/news/the-morse-code-no-other-actors-will-be-allowed-to-play-colin-dexter-sdetective-after-the-late-john-9213246.html, consulted 14 July 2019.

3. David Bishop, The Complete Inspector Morse, from the Original Series to the Screen, New edition, Titan Books, 2011, p. 15.

4. Bishop, p. 9.

5. Inspector Lewis pointedly establishes the filiation with Morse in its first episode and makes regular reference to him. The down-to-earth Lewis is now seconded by a Cambridge-educated Hathaway who in several ways may remind the viewer of Morse. Moreover, Oxford remains the main place and the series uses the same type of intrigue where Hathaway's academic education comes in handy.

6. Different writers (including Anthony Minghella and Danny Boyle) contributed to Morse (see Bishop and Jean-Pierre Esquenazi, "Morse/Frost: Prendre le temps de l'enquête", in Policiers et criminels, un genre populaire européen sur grand et petits écrans, ed. Raphaëlle Moine, Brigitte Rollet, Geneviève Sellier and Joël Augros, Paris, L'Harmattan, 2009, p. 253-262).

7. Linda Hutcheon, A Theory of Adaptation, New York and London, Routledge, 2006, p. 21.

8. Jason Mittell, Complex TV, The Poetics of Contemporary Television Storytelling, New York, NYUP, 2015, p. 7.

9. Yvonne Griggs, Adaptable TV, Rewiring the Text, London, Palgrave, 2018, p. 6.

10. Gérard Genette, Palimpsests: Literature in the Second Degree, Lincoln and London, University of Nebraska Press, 1997, p. 177.

11. Lubomír Doležel, Heterocosmica: Fiction and Possible Worlds, Baltimore, Johns Hopkins UP, 1998, p. 207.

12. Colin Dexter did return to his character in stories and in one of them he imagines Morse's undergraduate days: "Mr E. Morse, BA Oxon (Failed)" (2008), which is said to have inspired the idea of a TV prequel (see Bishop, p. 267).

13. This discussion will mostly focus on the very first Endeavour film that was shot and the first series it became part of because these may be the films that are particularly concerned with establishing the link with the former series.

14. In this respect, Endeavour is akin to an "origin story" which in comic books and film adaptations tells of the beginnings of a superhero or superheroine. 
15. As Richard Saint-Gelais reminds us (in Fictions transfuges, la transfictionnalité et ses enjeux, Paris, Seuil, 2011, p. 79), narrative desire as explained by Peter Brooks tends to lead us to know what happened next rather than what happened before.

16. Ben Davies, "Prequel Ontology and Temporality: The Thresholds of John Updike's Gertrude and Claudius", in Prequels, Coquels and Sequels in Contemporary Anglophone Fiction, ed. Armelle Parey, London, Routledge, 2019, p. 33 [p. 27-39].

17. H. Porter Abbott, The Cambridge Introduction to Narrative Theory, Cambridge, Cambridge University Press, 2008, p. 160.

18. Raphaël Baroni, La Tension narrative, Suspense, curiosité et surprise, Paris, Seuil, p. 285-286.

19. This explains why prequels are released and find an audience: Anthony Horowitz's James Bond novel (Forever and a Day, 2018) is a prequel; in the cinema, the second Indiana Jones film was a prequel to the first film. Christopher Campbell in 2014 identified a trend for prequels in American TV series ("What TV Show Should Get a Prequel Series While the Trend is Still Hot?", Film School Rejects, 23 July 2014, https://filmschoolrejects.com/what-tv-show-should-get-aprequel-series-while-the-trend-is-still-hot-2f40f10eb2f6/, consulted 14 July 2019).

20. Stéphane Benassi, "Sérialité(s)", in Décoder les séries TV, ed. Sarah Sepulchre, $2^{\text {nd }}$ edition, Deboeck supérieur, 2017, p. 84 [p. 79-114]. Translation mine.

21. Benassi, p. 84. Translation mine.

22. A fairly recent exception is P.D. James's Death comes to Pemberley (2011) that offers a sequel to Jane Austen's Pride and Prejudice in the shape of a crime novel.

23. Tzvetan Todorov, "Typologie du roman policier", Poétique de la prose, Paris, Seuil, 1971, p. 57 [p. 55-65].

24. "a story which has no importance in itself, which serves only as mediator between the reader and the story of the crime", Todorov, p. 46.

25. Esquenazi, p. 261 (translation mine).

26. See Benassi.

27. See Bishop for "the specials", p. 243.

28. Jason Mittell, "Previously on: Prime Time Serials and the Mechanics of Memory", Intermediality and Storytelling, No. 24, 2010, p. 78 [p. 78-98] (http://sites.middlebury.edu/jmittell/ files/2013/02/Mittell-Previously-On.pdf, consulted 14 July 2019).

29. The phenomenon has been observed by Benassi in the following words: "logique narrative générale sérielle tout en faisant évoluer les relations entre les personnages au fil des occurrences et en rendant apparent l'écoulement du temps diégétique", p. 81. See also p. 99.

30. In season 3, there is the overall suggestion that Morse may be in love with his superior's daughter but never dares to commit himself.

31. This is close to the combination of closed episodes and ongoing development of characters with the passing of time called "série feuilletonnante" by Benassi (see p. 99-100). Benassi's category includes mostly American and French instances of series constituted of 52-minute episodes, i.e. much shorter than Endeavour's.

32. Carolyn Jess-Cooke, "The Age of the \$equel: Beyond the Profit Principle", Film Sequels, Theory and Practice from Hollywood to Bollywood, Edinburgh, Edinburgh UP, 2009, p. 4 [p. 1-14].

33. Aristotle, Poetics, $1450 \mathrm{~b}$.

34. Colin Dexter, Last Seen Wearing [1976], The Second Inspector Morse Omnibus, Pan Books, 1998, p. 473.

35. Davies, p. 28.

36. Bishop, p. 16.

37. Dexter, Last Bus to Woodstock [1975], The Third Inspector Morse Omnibus, Pan Books, 1994, p. 19. (italics mine)

38. Dexter, Last Bus to Woodstock, p. 18, p. 19.

39. Dexter, Last Bus to Woodstock, p. 11. 
40. Dexter, Last Bus to Woodstock, p. 46.

41. Dexter, Last Bus to Woodstock, p. 46.

42. Dexter, Last Bus to Woodstock, p. 21, p. 36.

43. Dexter, Last Bus to Woodstock, p. 105. Morse's car was originally a Lancia: "In the original published versions of the early novels, Morse drove a Lancia. This was the only element Dexter retrospectively altered following the success of the TV series, swapping the Lancia for the more familiar Jaguar" (Bishop, p. 13).

44. "No one ever called Morse by his Christian name" (Dexter, Last Seen Wearing, p. 520); “'It's a funny thing' said Morse, 'but no one ever calls me by my Christian name"' (Dexter, Last Seen Wearing, p. 551); and in the first TV adaptation, when a character asks him for his first name, he eludes the answer.

45. http://www.mammothscreen.com/productions/shaun-evans-is-detective-constableendeavour-morse/, consulted 14 July 2019.

46. Georges Letissier, "Uncanny Repetitions: The Generative Power of the "Reader, I Married Him" Mantra in Tracy Chevalier's Anthology of Short Stories", in Parey (ed.), p. 182 [p. 177-194].

47. Saint-Gelais, p. 83. (Translation mine)

48. https://itvstudios.com/programmes/endeavour, consulted 14 July 2019.

49. Griggs, p. 6.

50. Amy Holdsworth, Television, Memory and Nostalgia, London, Palgrave MacMillan, 2011, p. 5.

51. Hutcheon, p. 120.

52. John Ellis, “The Literary Adaptation”, Screen, Vol. 23, No. 1, 1 May 1982, p. 3 [p. 3-5].

53. On this point, see Julie Sanders, Adaptation and Appropriation, London, Routledge, 2006, p. 25.

54. Michael Zeitlin, "Donald Barthelme and the Postmodern Sequel", in Part Two: Reflections of the Sequel, ed. Paul Budra and Betty A. Schellenberg, Toronto, University of Toronto Press, 1998, p. 162 [p. 160-173].

55. Paul Sutton, “Prequel: The 'Afterwardness' of the Sequel”, in Second Takes: Critical Approaches to the Film Sequel, ed. Carolyn Jess-Cooke and Constantine Verevis, Albany, State University of New York Press, 2010, p. 141, p. 142 [p. 139-51].

56. Kathy Mezei, “Jean Rhys' Wide Sargasso Sea: the Madwoman in the Attic Speaks (Out of Parenthesis Into Story)", in Historicité et métafiction dans le roman contemporain des îles britanniques, ed. Max Duperray, Aix en Provence, Université de Provence, 1994, p. 68 [p. 57-71].

57. Neil McCaw, "Morse, Heritage and the End of History", Adapting Detective Fiction. Crime, Englishness and the TV Detectives, London and New York, Continuum International Publishing, 2011, p. 62 [p. 60-74].

58. McCaw, p. 69.

59. McCaw, p. 63-69.

60. Racism is denounced at the beginning of "Arcadia" (S03E02), which ironically begins with white upper-class young men picking on two black men in a street in Oxford and throwing them in the river for no reason.

61. Colin Dexter's novels were blatantly intertextual, for instance with references to famous predecessors like Holmes and Poirot (Last Bus to Woodstock, p. 13) but also to Inspector Buckett in Bleak House: "I am Morse of the Detective, as Dickens would have said." (Last Bus Last Bus to Woodstock, p. 72).

62. Holdsworth, p. 113.

63. Saint-Gelais, p. 82. 


\section{ABSTRACTS}

This paper examines Endeavour (ITV, 2012-), a prequel to Colin Dexter's and ITV's Inspector Morse (1987-2000), which was initially aired in 2012 for the $25^{\text {th }}$ anniversary of Morse's first TV appearance. This new series introduced the audience to young Morse, played by Shaun Evans, at the time of his first years as police in Oxford. In so doing, the prequel reconstructs the past on the basis of threads in the source narrative. After discussing the specificities of the prequel genre in relation to Endeavour, this paper purports to examine the transformative effects of this reconstruction: how the prequel may or may not reconstruct the past of the hero, and how in so doing it may also reconstruct the memory of the viewer, his or her perception of the past, in terms of the source narrative.

Cet article examine Endeavour (ITV 2012-), prequel aux enquêtes de l'inspecteur Morse imaginées par Colin Dexter et ITV (1987-2000) et diffusé pour la première fois en 2012 à l'occasion du 25 anniversaire de la première apparition du policier à la télévision britannique. Cette nouvelle série suit le jeune inspecteur Morse, interprété par Shaun Evans, à l'époque de ses premières années dans la police à Oxford. Ce faisant, la série reconstruit le passé à partir de la trame du récit-source. Cet article examine d'abord les spécificités de l'expansion narrative que constitue un prequel de série télévisée avant de se pencher sur les transformations éventuelles opérées par cette reconstruction: comment le prequel reconstruit le passé du héros mais aussi la mémoire du spectateur et sa perception du passé.

\section{INDEX}

Mots-clés: prequel, Inspecteur Morse, Endeavour, mémoire, passé, Dexter Colin, Oxford Keywords: prequel, Inspector Morse, Endeavour, memory, representation of the past, Dexter Colin, Oxford

\section{AUTHOR}

\section{ARMELLE PAREY}

Armelle Parey is a senior lecturer at the Université de Caen Normandie. Her interests embrace narrative endings, memory and rewritings of the past in contemporary English-speaking fiction. She has recently edited Prequels, Coquels and Sequels in Contemporary Anglophone Fiction (Routledge, 2019). She also has an interest in adaptation. She has co-edited Happy Endings and Film (Houdiard, 2010) with Isabelle Roblin and Dominique Sipière, published on Austen's Sense and Sensibility and its adaptation by Ang Lee (Miranda [Online], No. 13, 2016) and on the television series Dickensian ( Études britanniques contemporaines [Online], No. 52, 2017). A collection entitled Adapting Endings from Book to Screen: Last Pages, Last Shots (edited with Shannon Wells-Lassagne) is forthcoming (Routledge). 
Armelle Parey est maître de conférences en anglais à l'université de Caen Normandie. Sa recherche porte sur les fins narratives, la mémoire et les réécritures du passé dans le roman anglophone contemporain. Elle a récemment dirigé Prequels, Coquels and Sequels in Contemporary Anglophone Fiction (Routledge, 2019). Elle s'intéresse également aux questions d'adaptation. Elle a ainsi co-dirigé Happy Endings and Film (Houdiard, 2010) avec Isabelle Roblin et Dominique Sipière, travaillé sur Sense and Sensibility de Jane Austen et son adaptation par Ang Lee (Miranda [En ligne], $\mathrm{n}^{\circ} 13,2016$ ) et sur la série télévisée Dickensian (Études britanniques contemporaines [En ligne], $\mathrm{n}^{\circ} 52$, 2017). Elle prépare actuellement la publication d'un recueil sur l'adaptation des fins à l'écran, codirigé avec Shannon Wells-Lassagne. 